\title{
Deep History Curricula under the Mandate of the Anthropocene
}

\author{
Insights from Interdisciplinary Shadow Places
}

FELIX RIEDE

\begin{abstract}
Whilst scientifically debated, the key insights encapsulated in the notion of the Anthropocene are profound: First, natural and cultural history - the fates of climate and the natural world on the one hand, and of humankind and its many cultures on the other - are conjoined. Second, human history is certainly not an inevitable history of progress but one potentially towards catastrophe. These realizations are driven by the wicked perspectives of future climate change and the likelihood of dramatically negative consequences for life on Earth. Looking back into deep history, however, the same realizations also have implications for how we view the human past and what driving forces we view as causal. This, in turn, impinges significantly on how we teach deep and recent history, how we articulate it with other disciplines, and how we display it in children's books, school textbooks, teaching materials and in museums. With roots firmly in a specific academic discipline - archaeology - I here examine what the topsy-turvy perspective of the Anthropocene implies vis-à-vis the design of contemporary, relevant and sustainable history teaching and teaching resources for the classroom and for learning spaces such as museums. While a collapse of traditional disciplinary boundaries is impractical if not impossible, I draw on notions of dark pedagogy and disciplinary shadow places to highlight how Anthropocene deep history can connect knowledge domains from across the natural and social sciences. New visions for our future need, I suggest, new visions of our past.
\end{abstract}

KEYWORDS: Anthropocene; archaeology; history; nationalism

Some 20 years after its almost off-hand proposal (Crutzen and Stoermer, 2000), the notion of the Anthropocene - a new era in which humans collectively if unequally shape global climate and ecosystems - has become firmly established. So much so, in fact, that it is formally entertained as a new geological epoch. Earth history and decisions about its divisions into eons, eras, epochs, and ages are the disciplinary purview of the International Commission on Stratigraphy (ICS) ${ }^{1}$, under the aegis of the International Union of Geological Sciences (IUGS) ${ }^{2}$.

\footnotetext{
https://stratigraphy.org/.

https://www.iugs.org/.
} 
According to the IUGS' official and scientifically grueling protocol, the Anthropocene - with a suggested start date of 1950 corresponding to both the so-called Great Acceleration of human production, consumption and disposal and the measurable increase in nuclear bomb signatures across the globe - remains to be formally ratified as a new epoch. Debate continues, but the working group commissioned with elaborating the reasons for such a ratification have made their case (Zalasiewicz et al., 2017). Official ratification aside, the very notion of the Anthropocene has caused a great deal of scientific furor with some arguing for abandoning the term entirely, others arguing for different starting points, and others yet suggesting that it should be more appropriately viewed as a geological event (Bauer et al., 2021), or else as a conceptual lever but not a formally recognised geological unit (e.g. Brown et al., 2013; Bauer, 2015; Davis and Todd, 2017; Bauer and Ellis, 2018; Ruddiman, 2018; Zalasiewicz et al., 2019).

Many different scientific disciplines from across the human, social and natural sciences as well as the arts have contributed to the debate; indeed, many seemingly innocent aspects of the Anthropocene as geological epoch - its notion of a collective and homogenous humankind, its start date - are politically charged from the outset (Lewis and Maslin, 2015; Swanson, 2016; Bobette and Donovan, 2019). Claims that scientific work on issues of anthropogenic climate change and its geological fingerprint, the Anthropocene, occur independently of political processes and predilections have long been shown to be spurious (Oreskes, 2015). At the same time, climate modelling and its global perspective have assumed epistemic prominence and garnered considerable political leverage (Heymann, 2010; Rödder, Heymann and Stevens, 2020). It is precisely because of the evident and latent entanglement of earth history with human history, of the natural and the social sciences around the notion of the Anthropocene, that implications for how to tell and teach history emerge.

With a disciplinary starting point in archaeology - a discipline that itself is situated between the natural sciences, the social sciences and the humanities; between history and geology -1 here explore the pedagogical implications of the Anthropocene mandate (see Hussain and Riede, 2020 for an earlier attempt). I draw on and combine recently developed notions of 'dark pedagogy' (Laugesen, 2019; Lysgaard and Bengtsson, 2020) and 'shadow places' (Potter et al., 2020) to suggest that history teaching takes on quite a particular and powerful role in a pedagogy that is not only sensitive to future needs of systemic change, environmental ethics and new forms of citizenship, but that heeds the historical roots of both the quandaries of the Anthropocene and their possible solutions. I will illustrate the entanglements of political, economic and social history with the history of climate change and how these remain disjoined in pedagogical settings through two examples. First, I focus on the official Danish topical canon for history teaching in the formal classroom setting of primary school. Second, I draw on the more informal pedagogical setting of an industrial heritage museum. Together, these two select instances demonstrate just how much inertia and how little climate literacy there is across such pedagogical settings; the ways in which these histories are presented indexes pre-Anthropocene notions of causal relations and of relevance, making it hard for learners to appreciate the roots and severity of our contemporary concerns.

\section{Archaeology as Conjoined Deep Histories}

In a landmark paper, the well-known postcolonial historian Dipesh Chakrabarty explored the implications of contemporary anthropogenic climate change for thinking and writing about history (Chakrabarty, 2009). He suggested that, in contrast to traditional scholarship in history, ideational, economic and political history could no longer be adequately captured without also including climate history. For Chakrabarty, as for many of his colleagues (Winiwarter et al., 
2005; Behringer, 2006; Pfister, 2015; e.g. Adamson, Hannaford and Rohland, 2018; Degroot et al., 2021), climate had become an important agent - one among many - of historical change. Carefully balancing between climate determinism and traditional internalist explanations (cf. Hulme, 2011), this new history of climate and society is both planetary in its geographic scale (Latour and Chakrabarty, 2020) and deep in its temporal perspective (Dukes, 2013). It is also overtly political in stressing the conjoined nature of nationalism, capitalism and climate change, of the developing world order of the recent past and its relation to the Anthropocene (Chakrabarty, 2014; Malm and Hornborg, 2014).

In the sense that anthropogenic climate change and the Anthropocene represent the result of a deep historical development of the human niche (Boggs, 2016; Meneganzin, Pievani and Caserini, 2020), archaeology as deep history (Shryock, Smail and Earle, 2011) can be aligned with Chakrabarty's propositions, also in relation to its delicate relation to climate determinism (Livingstone, 2012). Moreover, archaeology as a disciplinary endeavor is inextricably linked with the emergence of modern nation-states; exploring the past scientifically has mostly been in the service of state identity legitimization and imperial expansion (Kohl and Fawcett, 1995; Díaz-Andreu and Champion, 1996; Kohl, 1998; Kjærgaard, 2006; Díaz-Andreu, 2007; Diachenko, 2016). Famously, the Danish antiquarian and museological pioneer Christian Jürgensen Thomsen (1788-1865) devised the so-called Three Age System - from Stone to Bronze to Iron - as a classificatory backbone to human deep history. This tripartite scheme already then prioritized technological innovation and the works of elites as drivers of history; it is strongly suggestive of teleological and progressive change, a notion that was fully in line with contemporaneous thinking (Klindt-Jensen, 1975; Gräslund, 1981). The work of Thomsen was highly influential, and is mentioned in every textbook on archaeology.

Slightly later, when academic disciplines were formalized in the context of the modern university, the placement of archaeology as an academic discipline alongside history in most European university systems decoupled it from the natural sciences and hence also from the environmental sciences. Whereas early practitioners were broadly educated across knowledge domains, the scholars of the second half of the $20^{\text {th }}$ century became increasingly specialized and, as a consequence, in part isolated. Yet, mapping Thomsen's Three Ages onto timelines of the Anthropcene sensitive to the environmental consequences of such major changes in human deep history underlines the correlative aspects and questions whether this collective historical trajectory is one towards betterment or catastrophe (Fig. 2). Somewhat playfully but also poignantly referencing Thomsen's Three Age System, the Anthropocene has also been called the 'Plastic Age' (Zalasiewicz et al., 2016) and in doing so, suggesting that new, humanly-made synthetic materials act as essential object proxies for a new human condition (cf. Hartman et al., 2017). 


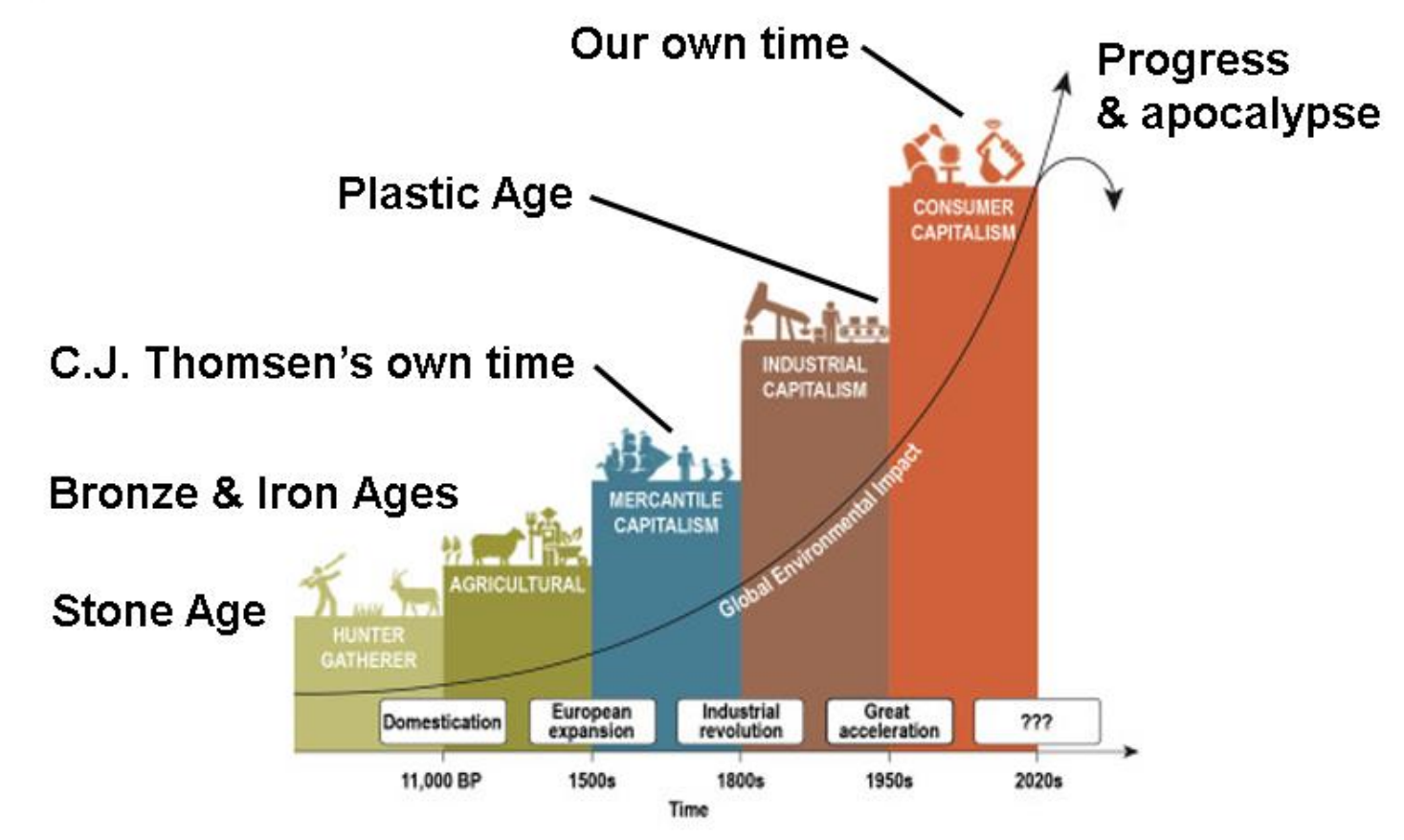

Figure 1 - Progressive national history in light of the Anthropocene. The fundamental structure of deep history and its causal process as conceptualized by Thomsen is of its time - progres-sivist, Eurocentric and colonial. Modified from Horton \& Horton (2019), original design by Lewis \& Maslin (2018)

Lest one was to think that the entanglements of nation-states and archaeology ceased long ago, or that they are hardly relevant to issues of contemporary climate change, it should be noted just how enthusiastically nationalist groups of the present mobilize archaeological heritage in their rhetoric (Hakenbeck, 2019), and how membership in such groups overlaps with attitudes of climate denialism (Forchtner, 2019). More benignly but no less importantly, administrative and legal structures related to the management of archaeological heritage are mostly national in their circumscription and so subtly perpetuate the notion that state-like ethnic identities have their roots in the deep past (Riede, 2017; e.g. Hakonen, 2021). Moreover, the framing of the deep past - in Europe at least - is orchestrated through institutions such as national museums (see Madsen and Jørgensen, 2010) and canonized national curricula. ${ }^{3}$ Globally, the canonical deep history and heritage of humanity are exemplified in the UNESCO World Heritage listing containing sites of supposed "outstanding value to humanity" somehow presupposing a human collective - the homognising 'Anthropos' of the Anthropocene - that glosses over historical and geopolitical inequalities. ${ }^{4}$

\section{Exploring the Shadow Places of Deep History}

Values are at the heart of selecting what is essential to preserve, communicate and teach. Assembling curricula and teaching resources involve the deliberate selection and de-selection of what is considered most vital. In the following, I will take issue with the portrayal of selected elements of these formal and informal educational resources in light of Anthropocene perspectives. In doing so, I will take inspiration from the notion of 'dark pedagogy' that

$3 \quad$ E.g. https://emu.dk/grundskole/historie/kanon?b=t5-t12

4 https://whc.unesco.org/en/list/?\&type=cultural. 
encourages an exploration of the uncanny, of the uncomfortable and the non-canonical; in addition, I draw on the idea of 'shadow places' and modify this to argue for increased exploration of inter-disciplinary articulations to tell the conjoined histories of the Anthropocene. In line with the arguments for disciplinary collapses above, it is increasingly difficult, I argue, to maintain lower-cycle educational structures that are strongly organized according to pre-Anthropocene principles, i.e. the social sciences, the natural sciences, the arts.

\section{The not-so-Deep History of Denmark - the Ertebølle Culture}

According to the Danish canonized history for educational purposes, pupils first meet deep history in the form of the Late Holocene Ertebølle culture. The Ertebølle culture holds iconic status in Denmark as it was the first pre-agricultural Stone Age culture discovered in the region (Fischer and Kristiansen, 2002). The then-groundbreaking investigation of the Ertebølle culture's renowned shell-middens became a paragon of early scientific archaeology (cf. Gron and Rowley-Conwy, 2018) - then explicitly framed in national and nationalistic terms (Kjærgaard, 2006) - and played an important role in the restitution of national identity and pride following a series of catastrophic conflicts and losses of territory (Kristiansen, 1993). Economically, Ertebølle people lived as foragers, hunters and fishers; they accumulated massive mounds of oyster and mussel shells; there is little sign of social or political stratification, of sickness or wealth disparity and limited signs of conflict - it has traditionally been seen as harmonious, healthy and just - the Nordic "original affluent society" (cf. Rowley-Conwy, 2001).

The choice of opening a national history curriculum with the Ertebølle culture is highly significant politically. The geographic extent of the Ertebølle culture coincides with the somewhat extended historical national boundaries of the Danish state (i.e. including Scania and parts of northern Germany). This geography is highly suggestive of a deep ethnic and political ancestry of the nation. Popular reconstructions of the Ertebølle culture focus on crafts and labour, and gender roles; they are tidy, romantic and essentializing - all feeding into the associated master narrative (sensu McLean and Syed, 2015) of national self-identity and good citizenship (Fig.2). 


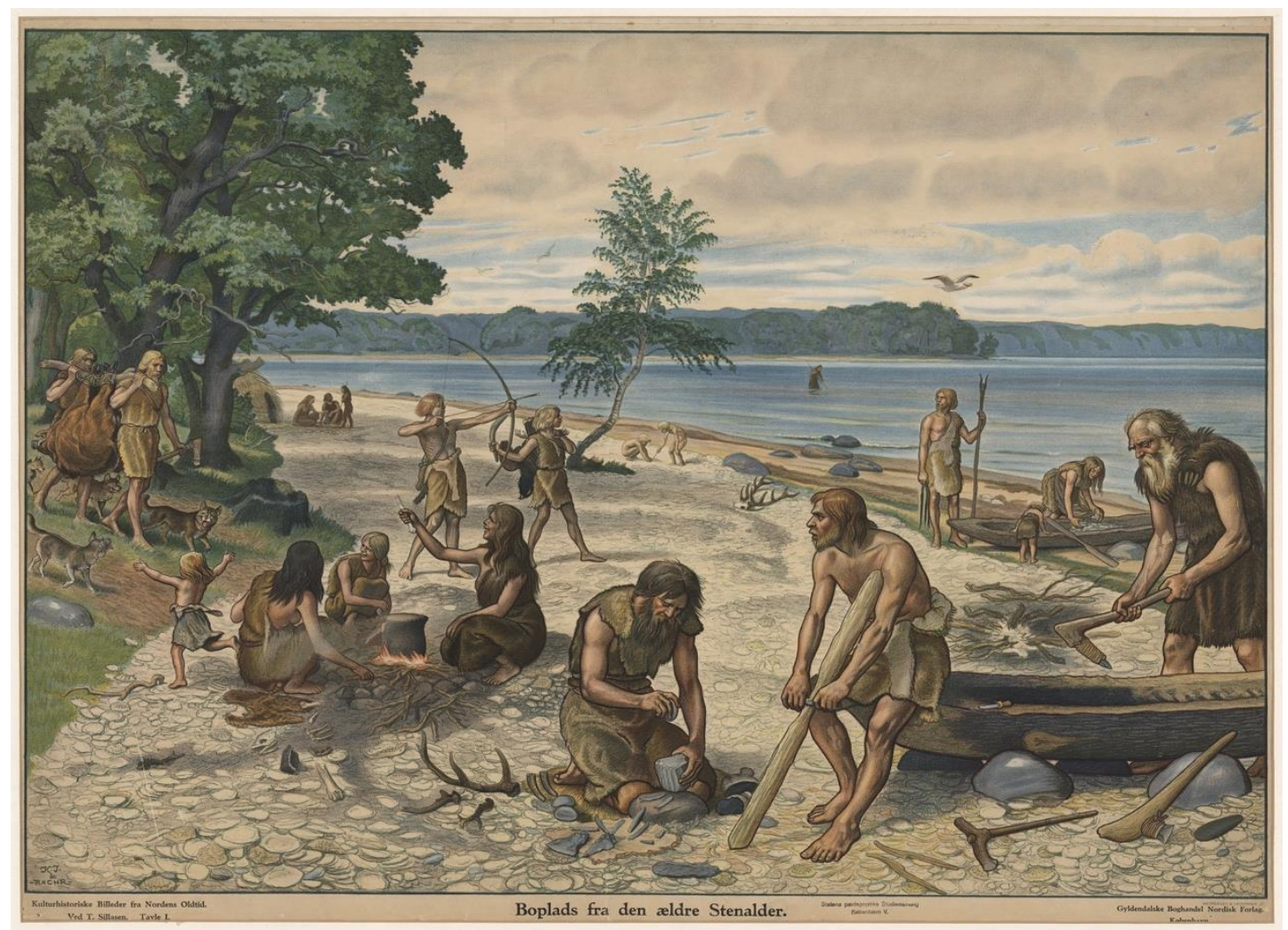

Figure 2 - An iconic scene from the Ertebølle culture produced for classroom display and teaching, from Sillasen

(1925). Image courtesy of https://skolehistorie.au.dk/samlinger/anskuelsesbilleder/.

As a discipline tightly linked to the genesis of modern nation-states, such portrayals can be read as part of the ideological legitimization ( $\mathrm{H} \varnothing \mathrm{gh}, 2009$ ). This may not be the crass propaganda of authoritarian regimes (Arnold, 1990; Shnirel'man, 2013), yet in selectively displaying certain bodily ideals, certain relations of labour and gender, such powerful visual aids form and naturalize particular views of history - in this case one of harmony and order but also of Caucasian able-bodiedness and of conformity. Pedagogical wall displays were widespread in Denmark in especially the $19^{\text {th }}$ and first part of the $20^{\text {th }}$ centuries (Glenstrup, 1991; GrinderHansen, 1997); an extensive collection is today curated by the Royal Library (Thuesen, 1980). ${ }^{5}$ While such display material is now somewhat antiquated, the image of the Ertebølle culture and its choice as the opening entry of a national primary school curriculum remains deeply entrenched in a pre-Anthropocene worldview.

Recent research could, however, be used to tell a somewhat different-darker, more shadowy - story, one of socio-ecological fragility (Gronenborn, 2005), of political complexity and ambition (Fischer, 2002), of wide-ranging networks (Jordan and Zvelebil, 2009), and of dark skin (Olalde et al., 2014). The accumulation of shell-mounds, so strongly associated with the Ertebølle culture but which also occurs in many other places across the world, has itself been proposed as a marker of an alternative and much earlier start date of the Anthropocene (Erlandson, 2013). Moreover, the Ertebølle culture itself also interacted with expanding farming populations and could thus provide a stage for discussing the societal and - most pertinently here - environmental consequences of agriculture then (Ruddiman, 2003) and now. Notably, some of the official teaching material related to the Ertebølle culture does suggest

5 https://skolehistorie.au.dk/samlinger/anskuelsesbilleder/ 
climate change as a driver for the transition to agriculture. ${ }^{6}$ This is in principle laudable, but given the complete absence of climatic or environmental factors as historical drivers in the remainder of the canon, this single mention merely perpetuates the notion that climate change was important back in deep time, but that with the advent of agriculture, political and economic processes alone were causal. This is precisely the disjoining of climate history from human history that Chakrabarty critiqued. In addition, in doing so, this extremely limited inclusion of climate in the historical curriculum also strongly reinforces linear and progressive notions of history, from primitive to sophisticated, from worse to better. This is precisely the outdated master narrative that Malm \& Hornborg critiqued.

\section{Anthropocene Pedagogy in the Museum - the Former Lignite Mine of Søby}

At the former open-cast lignite mine of $\$ \varnothing$ by in central Denmark, low-grade brown coal was extracted for domestic and industrial use between 1940 and 1970. In particular, Søby grew during the years of the Second World War due to interrupted supply lines from Great Britain. In the post-war years, Søby was Denmark's largest coal mine and its growth is commonly described as a 'Klondike'-like economic adventure (Rolsted, 2006; Svendsen, 2007). This landscape is today managed by the Danish Nature Agency and is home to many invasive plant species (Sørensen, 1986). Industrial heritage such as the Søby mine has found its way on UNESCO's World Heritage list where, most commonly, aspects of technological innovation and revolution are emphasized and valorized. Similarly, in the small museum attached to the Søby mining area, a sanitized, romanticized and masculine story of hard work and entrepreneurship is told.

What is downplayed in this version is the environmental consequence of the mining activities on the local landscape, which has been radically transformed into a complex, feral and awkward multispecies collage (Brichet and Hastrup, 2018; Bubandt and Tsing, 2018). The pedagogical interface of the museum setting is also not currently used to situate $S \varnothing$ by in the broader complexities of the Anthropocene. If one was to accept the proposed starting date of 1950 for the Anthropocene, then Søby's heyday spans exactly this transition. A critical factor in pointing at 1950 as an appropriate starting point for the Anthropocene epoch are the globally detectable radioactive traces of extensive nuclear testing in the immediate post-war era. Archaeological fieldwork at $\$ \varnothing$ by found unmistakable traces of such nuclear enrichment in the sediments and also unearthed material proxies for the beginning of the Plastic Age and its associated rearrangements of production, consumption and discard (Fig.3; Riede, Vestergaard and Fredensborg, 2016; Vestergaard and Riede, 2016, 2017).

6 E.g. https://emu.dk/grundskole/historie/kanon/historiekanon?b=t5-t12-t64.

178

Deep History Curricula under the Mandate of the Anthropocene

Futures of Education, Culture \& Nature - Learning to Become 

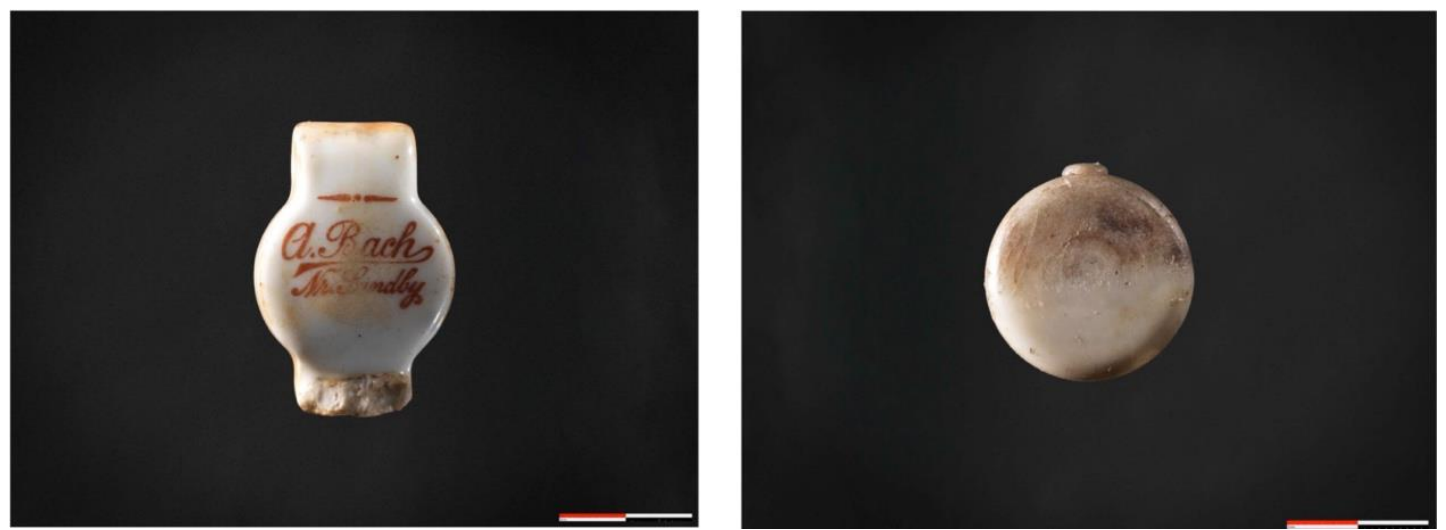

Figure 3 - Material markers of the Anthropocene. Left: a regionally produced reusable (and heavily reused - note the wear traces at the bottom) bottle cap from the pre-Anthropocene layers at Søby. Right: an anonymous, almost certainly not locally produced single-use plastic bottle cap from the Anthropocene layers at Søby. Note also that plastic itself not only requires energy generated by fossil fuels for its making, but it is also partly made of fossil resources itself. Its eventual deposition at a site of fossil fuel extraction marks the closure of the vicious cycle of Anthropocene production, consumption and use of these non-renewable resources.

Many of the archaeological finds from the excavation at $\$ \varnothing b y$ but also those objects curated in the Søby museum speak directly to the exploding industry and consumption that characterized the time after 1950. They are evidently artefacts of the Great Acceleration and afford the possibility of linking complex global patterns of socio-political, economic and climatic change to very local, quotidian and even intimate narratives. Søby itself is a shadow place and it provides a remarkable opportunity to explore the darker aspects of recent history. Such exploration was in fact attempted in a temporary exhibition at Moesgård Museum in 2015, where objects from the Søby excavations were displayed and linked directly to Anthropocene concerns (Brichet, Hastrup and Riede, 2017). Treating the archaeological finds as so-called hyperobjects that encapsulate social, political and environmental relations (Hudson, 2014; cf. Campbell, 2021), this exhibition was deliberately designed as a dark pedagogical alternative or indeed counter-narrative to the canonical one presented in the museum at $\$ \varnothing b y$ itself.

\section{Teaching History in the Anthropocene}

In a recent paper with the title "Teaching climate change in the Anthropocene: An integrative approach", Leichenko \& O'Brien (2020) strongly question that the current focus on scientific literacy and on the physical dynamics of climate change serve college and university students well in meeting the climate crisis. Their suggested solution - for higher education - is a radical dissolution of disciplinary boundaries and an integration across Social Science and Natural Science perspectives. In the Humanities, similar discipline-defying pedagogical developments are underway under the umbrella of the so-called Environmental Humanities (Siperstein, Lemenager and Hall, 2016; O'Gorman et al., 2019); university scholars are increasingly questioning what role higher education plays in the knowledge ecology of the Anthropocene - and to what degree its role is not least to formulate timely alternatives to the increasingly obsolete master narratives entrenched in disciplinary and political inerita (Wright, 2016). But can a radical rejection of disciplinary cores be implemented in formal primary school and informal pedagogy? How can we appropriately teach deep history in the Anthropocene?

There are no simple answers to these questions. Without disciplinary knowledge, making a case for the historical depth of the Anthropocene is impossible. Without disciplinary knowledge, making connections between factors traditionally seen as disparate is impossible. 
Yet, there is little doubt that ring-fenced pedagogies that isolate history from climate, nature from culture are becoming less and less suitable for meeting the concerns of the present and of future generations (cf. Wals et al., 2014). In the museum sector, there a strong forces pushing towards active engagement with the climate crisis (e.g. Cameron and Neilson, 2015; Rees, 2017) with some practitioners even arguing for activistic engagement and major re-designs of exhibitions in light of the Anthropocene (Cameron, 2019; Lyons and Bosworth, 2019; Arfvidsson and Follin, 2020). Yet, the institutional structures - with more or less silotised museums of natural history and museums of culture history, as well as national museums whose remit is inherently tied to nation-state narrarives - do neither naturally assist in dissolving disciplinary and conceptual boundaries, nor do they lend themselves easily to the formulations of alternative narratives. The structures of these education settings, too, remain firmly preAnthropocene.

In many countries - in this paper exemplified by Denmark - primary school curricula share this pre-Anthropocene design. While topics of climate change and sustainability are rising to the fore across many subjects, the fundamental compartmentalization of knowledge into different domains, coupled with the canonization of national history as the measure of historical awareness, does not per se promote the realization of Anthropocene entanglements. The current curriculum is expressly designed to provide historical resources for identiy construction and to allow pupils to situate themselves in a larger and longer societal timeline. In its narrow scope, however, it arguably fails to to provide a master narrative (i.e. one of Eurocentric progress) that resonates with the emergences of personal narratives among current generations as they become keenly concerned with issues of climate change, resilience, suistanability and attendant social justice issues (cf. McLean and Syed, 2015).

It is therefore that this paper has suggested a turn towards the shadow places of national history and the use of dark pedagogy that deliberately subverts some aspects of these traditional domains. Fortunately, teachers and educators - whether in schools, museums or other settings - can in practice work relatively flexibly with the essential framing of even canonized teaching content if they themselves have the knowledge and tools. For instance, the Ertebølle culture and the classic teaching materials associated with it can be set within an Anthropocene context, museum displays can be augmented and contextualized through analogue and digital means. $^{7}$

History demonstrates above else that culture change is possible over time. In this, the transmission of information from one generation to the next is the essential mechanism driving change. Different forms of social learning and teaching can accelerate this process, or slow it down (cf. Brewer and Riede, 2018). Dramatic effects of climate change on life quality are no more than a generation away (Lyon et al., 2021; Thiery et al., 2021). Our knowledge of the past feeds into our ways of imaging the furture - this knowledge enables and constrains our worldmaking (see Vervoort et al., 2015). Teaching history in the Anthropocene must shoulder the pedagogical responsibility of looking not just to the past - no longer a robust analogue for our future - but to what is to come. Short of a comprehensive transformation of curricular structures across all educational sectors, this responsibility can be met in the disciplinary shadow places and via dark pedagogies that embrace the complexities and entanglements of our time head on.

7 E.g. https://skolehistorie.au.dk/digitale-udstillinger/det-gode-liv-i-oldtiden/.

180

Deep History Curricula under the Mandate of the Anthropocene

Futures of Education, Culture \& Nature - Learning to Become 


\section{Literature}

Adamson, G.C.D., Hannaford, M.J. and Rohland, E.J. (2018) 'Re-thinking the present: The role of a historical focus in climate change adaptation research', Global Environmental Change, 48, pp. 195-205. doi:https://doi.org/10.1016/j.gloenvcha.2017.12.003.

Arfvidsson, H. and Follin, A. (2020) 'Connectedness, consumption and climate change: the exhibition human nature', Museum Management and Curatorship, 35(6), pp. 684-696. doi:10.1080/09647775.2020.1842237.

Arnold, B. (1990) 'The past as propaganda: totalitarian archaeology in Nazi Germany', Antiquity, 64(244), pp. 464-478.

Bauer, A.M. (2015) 'Questioning the Anthropocene and Its Silences: Socioenvironmental History and the Climate Crisis', Resilience: A Journal of the Environmental Humanities, 3, pp. 403-426.

Bauer, A.M. et al. (2021) 'Anthropocene: event or epoch?', Nature, 597(7876), pp. 332-332.

Bauer, A.M. and Ellis, E.C. (2018) 'The Anthropocene Divide: Obscuring Understanding of SocialEnvironmental Change', Current Anthropology, 59(2), pp. 209-227. doi:10.1086/697198.

Behringer, W. (2006) Kulturgeschichte des Klimas: von der Eiszeit bis zur globalen Erwärmung. München: C.H. Beck.

Bobette, A. and Donovan, A.R. (2019) Political Geology. Active Stratigraphies and the Making of Life. London: Palgrave Macmillan.

Boggs, C. (2016) 'Human Niche Construction and the Anthropocene', in Emmett, R.S. and Lekan, T. (eds) Whose Anthropocene? Revisiting Dipesh Chakrabarty's 'Four Theses'. München: Rachel Carson Centre (RCC Perspectives: Transformations in Environment and Society), pp. 2731.

Brewer, J. and Riede, F. (2018) 'Cultural heritage and climate adaptation: a cultural evolutionary perspective for the Anthropocene', World Archaeology, pp. 1-16. doi:10.1080/00438243.2018.1527246.

Brichet, N.S. and Hastrup, F. (2018) 'Industrious Landscaping: The Making and Managing of Natural Resources at Søby Brown Coal Beds', Journal of Ethnobiology, 38(1), pp. 8-23. doi:10.2993/0278-0771-38.1.008.

Brichet, N.S., Hastrup, F. and Riede, F. (2017) 'Mild Apocalypse - Feral Landscapes in Denmark: Reflections on an Exhibition', Engagement Blog.

Brown, A.G. et al. (2013) 'The Anthropocene: is there a geomorphological case?', Earth Surface Processes and Landforms, 38(4), pp. 431-434. doi:10.1002/esp.3368.

Bubandt, N. and Tsing, A. (2018) 'An Ethnoecology for the Anthropocene: How A Former BrownCoal Mine in Denmark Shows Us the Feral Dynamics of Post-Industrial Ruin', Journal of Ethnobiology, 38(1), pp. 1-13 (Supplement).

Cameron, F.R. (2019) 'Stirring up Trouble: Museums as Provocateurs and Change Agents in Polycentric Alliances for Climate Change Action', in Leal Filho, W., Lackner, B., and McGhie, H. (eds) Addressing the Challenges in Communicating Climate Change Across Various Audiences. Cham: Springer International Publishing, pp. 647-673.

Cameron, F.R. and Neilson, B. (eds) (2015) Climate Change and Museum Futures. London: Routledge (Routledge Research in Museum Studies).

Campbell, P.B. (2021) 'The Anthropocene, hyperobjects and the archaeology of the future past', Antiquity. 2021/08/19 edn, pp. 1-16. doi:10.15184/aqy.2021.116.

Chakrabarty, D. (2009) 'The Climate of History: Four Theses', Critical Inquiry, 35(2), pp. 197-222. doi:10.1086/596640.

Chakrabarty, D. (2014) 'Climate and Capital: On Conjoined Histories', Critical Enquiry, 41, pp. 123. 
Crutzen, P.J. and Stoermer, E.F. (2000) 'The Anthropocene', Global Change Newsletter, 41, pp. $17-18$.

Davis, H. and Todd, Z. (2017) 'On the importance of a date, or, decolonizing the Anthropocene', ACME: An International Journal for Critical Geographies, 16(4), pp. 761-780.

Degroot, D. et al. (2021) 'Towards a rigorous understanding of societal responses to climate change', Nature, 591(7851), pp. 539-550. doi:10.1038/s41586-021-03190-2.

Diachenko, A. (2016) 'Archaeology and the nation state. The case of eastern Europe', Archaeological Dialogues. 2016/05/20 edn, 23(1), pp. 3-10. doi:10.1017/\$1380203816000039.

Díaz-Andreu, M. (2007) A World History of Nineteenth-Century Archaeology. Nationalism, Colonialism, and the Past. Oxford: Oxford University Press (Oxford Studies in the History of Archaeology).

Díaz-Andreu, M. and Champion, T. (eds) (1996) Nationalism and archaeology in Europe. London: UCL Press.

Dukes, P. (2013) 'Big History, Deep History and the Anthropocene', History Today, 63(11), pp. 45.

Erlandson, J.M. (2013) 'Shell middens and other anthropogenic soils as global stratigraphic signatures of the Anthropocene', Anthropocene, 4(0), pp. 24-32. doi:http://dx.doi.org/10.1016/j.ancene.2013.12.001.

Fischer, A. (2002) 'Food for Feasting? An evaluation of explanations of the neolithisation of Denmark and southern Sweden', in Fischer, A. and Kristiansen, K. (eds) The Neolithisation of Denmark - 150 Years of Debate. Sheffield: J.R. Collis (Sheffield Archaeological Monographs, 15), pp. 343-393.

Fischer, A. and Kristiansen, K. (2002) The Neolithisation of Denmark. 150 Years of Debate. Sheffield: J.R. Collins Publications.

Forchtner, B. (2019) 'Climate change and the far right', Wiley Interdisciplinary Reviews: Climate Change, 10(5), p. e604. doi:10.1002/wcc.604.

Glenstrup, C. (1991) 'På jagt i en billedskat', Uddannelseshistorie, 1991, pp. 75-86.

Gräslund, B. (1981) 'The background to C.J. Thomsen's Three Age System', in Daniel, G. (ed.) Towards a History of Archaeology. London: Thames \& Hudson, pp. 45-50.

Grinder-Hansen, K. (1997) 'Til anskuelse og fordybelse', Siden Saxo, 14(3), pp. 8-17.

Gron, K.J. and Rowley-Conwy, P. (2018) 'Environmental Archaeology in Southern Scandinavia', in Pişkin, E., Marciniak, A., and Bartkowiak, M. (eds) Environmental Archaeology: Current Theoretical and Methodological Approaches. Cham: Springer International Publishing, pp. 35-74.

Gronenborn, D. (ed.) (2005) Klimaveränderung und Kulturwandel in neolithischen Gesellschaften Mitteleuropas, 6700-2200 v. Chr. Mainz: Verlag des Römisch-Germanisches Zentralmuseums (RGZM-Tagung 1).

Hakenbeck, S.E. (2019) 'Genetics, archaeology and the far right: an unholy Trinity', World Archaeology, pp. 1-11. doi:10.1080/00438243.2019.1617189.

Hakonen, A. (2021) 'Communities Beyond Society: Divergence of Local Prehistories on the Bothnian Arc, Northern Europe', Open Archaeology, 7(1), pp. 211-230. doi:10.1515/opar-20200132.

Hartman, S. et al. (2017) 'Medieval Iceland, Greenland, and the New Human Condition: A case study in integrated environmental humanities', Global and Planetary Change [Preprint]. doi:http://dx.doi.org/10.1016/j.gloplacha.2017.04.007.

Heymann, M. (2010) 'The evolution of climate ideas and knowledge', Wiley Interdisciplinary Reviews: Climate Change, 1(4), pp. 581-597. doi:10.1002/wcc.61.

Høgh, L. (2009) 'Guldalderens nedrustning - en renæssance for den strategiske arkæologi?', Arkæologisk Forum, 2009(særnummer), pp. 2-5. 
Horton, P. and Horton, B.P. (2019) 'Re-defining Sustainability: Living in Harmony with Life on Earth', One Earth, 1(1), pp. 86-94. doi:10.1016/j.oneear.2019.08.019.

Hudson, M.J. (2014) 'Dark artifacts: Hyperobjects and the archaeology of the anthropocene', Journal of Contemporary Archaeology, 1(1), pp. 82-86. doi:10.1558/jca.v1i1.82.

Hulme, M. (2011) 'Reducing the Future to Climate: A Story of Climate Determinism and Reductionism', Osiris, 26(1), pp. 245-266. doi:10.1086/661274.

Hussain, S.T. and Riede, F. (2020) 'Paleoenvironmental humanities: Challenges and prospects of writing deep environmental histories', WIREs Climate Change, 11(5), p. e667. doi:10.1002/wcc.667.

Jordan, P. and Zvelebil, M. (2009) Ceramics before farming: the dispersal of pottery among prehistoric Eurasian hunter-gatherers. Walnut Creek, CA: Left Coast Press (Publications of the Institute of Archaeology, University College London).

Kjærgaard, P.C. (2006) "To the Benefit of Mankind, To Honour the Nation": National Identity in an International World of Science', in Siegmund-Schultze, R. and Kragh Sørensen, H. (eds) Perspectives on Scandinavian Science in the Early Twentieth Century. Oslo: Novus Forlag (Dansk Naturvidenskabs Historie, vol. 3), pp. 265-284.

Klindt-Jensen, O. (1975) A History of Scandinavian Archaeology. London: Thames \& Hudson.

Kohl, P.L. (1998) 'NATIONALISM AND ARCHAEOLOGY: On the Constructions of Nations and the Reconstructions of the Remote Past', Annual Review of Anthropology, 27(1), pp. 223-246. doi:10.1146/annurev.anthro.27.1.223.

Kohl, P.L. and Fawcett, C. (1995) Nationalism, politics, and the practice of archaeology. Cambridge: Cambridge University Press.

Kristiansen, K. (1993) 'The Strength of the Past and its Great Might: An Essay on the Use of the Past', Journal of European Archaeology, 1(1), pp. 3-32. doi:10.1179/096576693800731172.

Latour, B. and Chakrabarty, D. (2020) 'Conflicts of Planetary Proportion - A Conversation', Journal of the Philosophy of History, 14(3), pp. 419-454.

Laugesen, M.H.-L. (2019) 'Dark Pedagogy in the Anthropocene', in Lysgaard, J.A., Bengtsson, S., and Laugesen, M.H.-L. (eds) Dark Pedagogy: Education, Horror and the Anthropocene. Cham: Springer International Publishing, pp. 103-141. doi:10.1007/978-3-030-19933-3_6.

Leichenko, R. and O'Brien, K. (2020) 'Teaching climate change in the Anthropocene: An integrative approach', Anthropocene, 30, p. 100241. doi:10.1016/j.ancene.2020.100241.

Lewis, S.L. and Maslin, M.A. (2015) 'Defining the Anthropocene', Nature, 519(7542), pp. 171-180. doi:10.1038/nature14258.

Lewis, S.L. and Maslin, M.A. (2018) Human planet: how we created the anthropocene, Human planet : how we created the anthropocene /. London: Pelican.

Livingstone, D.N. (2012) 'Changing Climate, Human Evolution, and the Revival of Environmental Determinism', Bulletin of the History of Medicine, 86(4), pp. 564-595. doi:doi:10.1353/bhm.2012.0071.

Lyon, C. et al. (2021) 'Climate change research and action must look beyond 2100', Global Change Biology, n/a(n/a). doi:10.1111/gcb.15871.

Lyons, S. and Bosworth, K. (2019) 'Museums in the climate emergency', in Janes, R.R. and Sandell, R. (eds) Museum activism. London: Routledge.

Lysgaard, J.A. and Bengtsson, S. (2020) 'Dark pedagogy - speculative realism and environmental and sustainability education', Environmental Education Research, 26(9-10), pp. 1453-1465. doi:10.1080/13504622.2020.1739230.

Madsen, P.K. and Jørgensen, L. (eds) (2010) 'The national museums in a globalised world: a conference on the bicentenary of The National Museum of Denmark, Copenhagen May 21-22 2007.', in. Copenhagen: National Museum of Denmark. 
Malm, A. and Hornborg, A. (2014) 'The geology of mankind? A critique of the Anthropocene narrative', The Anthropocene Review, 1(1), pp. 62-69. doi:10.1177/2053019613516291.

McLean, K.C. and Syed, M. (2015) 'Personal, Master, and Alternative Narratives: An Integrative Framework for Understanding Identity Development in Context', Human Development, 58(6), pp. 318-349. doi:10.1159/000445817.

Meneganzin, A., Pievani, T. and Caserini, S. (2020) 'Anthropogenic climate change as a monumental niche construction process: background and philosophical aspects', Biology \& Philosophy, 35(4), p. 38. doi:10.1007/s10539-020-09754-2.

O'Gorman, E. et al. (2019) 'Teaching the Environmental Humanities: International Perspectives and Practices', Environmental Humanities, 11(2), pp. 427-460. doi:10.1215/220119197754545 .

Olalde, I. et al. (2014) 'Derived immune and ancestral pigmentation alleles in a 7,000-year-old Mesolithic European', Nature, advance online publication. doi:10.1038/nature12960 http://www.nature.com/nature/journal/vaop/ncurrent/abs/nature12960.html\#supplementary-information.

Oreskes, N. (2015) 'How Earth Science Has Become a Social Science', Historical Social Research / Historische Sozialforschung, 40(2 (152)), pp. 246-270.

Pfister, C. (2015) 'Weather, Climate and the Environment', in Scott, H. (ed.) The Oxford Handbook of Early Modern European History, 1350-1750. Oxford: Oxford University Press, pp. 70-93. Available at: DOI:10.1093/oxfordhb/9780199597253.013.2.

Potter, E. et al. (2020) 'A manifesto for shadow places: Re-imagining and co-producing connections for justice in an era of climate change', Environment and Planning E: Nature and Space, p. 2514848620977022 . doi:10.1177/2514848620977022.

Rees, M. (2017) 'Museums as catalysts for change', Nature Climate Change, 7, p. 166. doi:10.1038/nclimate3237.

Riede, F. (2017) 'The "Bromme problem" - notes on understanding the Federmessergruppen and Bromme culture occupation in southern Scandinavia during the Allerød and early Younger Dryas chronozones', in Sørensen, M. and Buck Pedersen, K. (eds) Problems in Palaeolithic and Mesolithic Research. Copenhagen: University of Copenhagen \& Museum of Southeast Denmark (Arkæologiske Studier vol. 12), pp. 61-85.

Riede, F., Vestergaard, C. and Fredensborg, K.H. (2016) 'A field archaeological perspective on the Anthropocene', Antiquity, 90(354), p. e7 (1-5). doi:10.15184/aqy.2016.183.

Rödder, S., Heymann, M. and Stevens, B. (2020) 'Historical, Philosophical, and Sociological Perspectives on Earth System Modeling', Journal of Advances in Modeling Earth Systems, 12(10), p. e2020MS002139. doi:10.1029/2020MS002139.

Rolsted, J. (2006) Søby klondyke: En sandfærdig skildring af forholdene i Søby brunkulslejer i årene 1940-1950. 2. udgave. Herning: Stout.

Rowley-Conwy, Peter (2001) 'Time, change and the archaeology of hunter-gatherers: how original is the "original affluent society"?', in Panter-Brick, C., Layton, R.H., and Rowley-Conwy, P. (eds) Hunter-gatherers: an interdisciplinary perspective. Cambridge: Cambridge University Press, pp. 39-72.

Ruddiman, W.F. (2003) 'The Anthropogenic Greenhouse Era Began Thousands of Years Ago', Climatic Change, 61(3), pp. 261-293.

Ruddiman, W.F. (2018) 'Three flaws in defining a formal "Anthropocene"', Progress in Physical Geography: Earth and Environment, 42(4), pp. 451-461. doi:10.1177/0309133318783142.

Shnirel'man, V.A. (2013) 'Nationalism and Archeology', Anthropology \& Archeology of Eurasia, 52(2), pp. 13-32. doi:10.2753/AAE1061-1959520202. 
Shryock, A., Smail, D.L. and Earle, T.K. (2011) Deep history: the architecture of past and present. Berkeley: University of California Press.

Sillasen, T. (1925) Danmarks Oldtid: tekst til Kulturhistoriske billeder fra Nordens oldtid. København: Gyldendal.

Siperstein, S., Lemenager, S. and Hall, S. (eds) (2016) Teaching Climate Change in the Humanities. New York: Routledge.

Sørensen, P.M. (1986) Søby brunkulslejer: helhedsplanlægning - botanisk registrering. Kolding: Gruppen for by- og landskabsplanlægning.

Svendsen, J. (2007) Det brune guld: Brunkulseventyret i Danmark. 1. udgave. Brande: DialogForum.

Swanson, H.A. (2016) 'Anthropocene as Political Geology: Current Debates over how to Tell Time', Science as Culture, 25(1), pp. 157-163. doi:10.1080/09505431.2015.1074465.

Thiery, W. et al. (2021) 'Intergenerational inequities in exposure to climate extremes', Science, 374(6564), pp. 158-160. doi:10.1126/science.abi7339.

Thuesen, I.-B. (1980) 'Anskuelsesbilleder: En orientering om billedsamlingen på Danmarks pædagogiske Bibliotek', Årbog for Dansk Skolehistorie, 14(1980), pp. 87-100.

Vervoort, J.M. et al. (2015) 'Scenarios and the art of worldmaking', Futures, 74, pp. 62-70. doi:10.1016/j.futures.2015.08.009.

Vestergaard, C. and Riede, F. (2016) 'Samtidsarkæologi ved Søby', Midtjyske Fortællinger, 2016, pp. 55-65.

Vestergaard, C. and Riede, F. (2017) 'Modern climate change and contemporary environmental archaeology?', Archaeological Review from Cambridge, 32(2), pp. 10-24.

Wals, A.E.J. et al. (2014) 'Convergence Between Science and Environmental Education', Science, 344(6184), pp. 583-584. doi:10.1126/science.1250515.

Winiwarter, V. et al. (2005) 'Environmental History in Europe from 1994 to 2004: Enthusiasm and Consolidation', 10(4), pp. 501-530.

Wright, S. (2016) 'Universities in a knowledge economy or ecology? Policy, contestation and abjection', Critical Policy Studies, 10(1), pp. 59-78. doi:10.1080/19460171.2016.1142457.

Zalasiewicz, J. et al. (2016) 'The geological cycle of plastics and their use as a stratigraphic indicator of the Anthropocene', Anthropocene, 13, pp. 4-17. doi:http://dx.doi.org/10.1016/j.ancene.2016.01.002.

Zalasiewicz, J. et al. (2017) 'The Working Group on the Anthropocene: Summary of evidence and interim recommendations', Anthropocene, 19(Supplement C), pp. 55-60. doi:https://doi.org/10.1016/j.ancene.2017.09.001.

Zalasiewicz, J. et al. (2019) 'A formal Anthropocene is compatible with but distinct from its diachronous anthropogenic counterparts: a response to W.F. Ruddiman's "three flaws in defining a formal Anthropocene"', Progress in Physical Geography: Earth and Environment, 43(3), pp. 319-333. doi:10.1177/0309133319832607. 